August 2011

\title{
Did Newsnight Miss the Story? A Survey of How the BBC's “Flagship Political Current Affairs Program” Reported Genocide and War in Rwanda between April and July 1994
}

Georgina Holmes

Follow this and additional works at: https://digitalcommons.usf.edu/gsp

\section{Recommended Citation}

Holmes, Georgina (2011) "Did Newsnight Miss the Story? A Survey of How the BBC's "Flagship Political Current Affairs Program" Reported Genocide and War in Rwanda between April and July 1994," Genocide Studies and Prevention: An International Journal: Vol. 6: Iss. 2: Article 7.

Available at: https://digitalcommons.usf.edu/gsp/vol6/iss2/7

This Articles is brought to you for free and open access by the Open Access Journals at Digital Commons @ University of South Florida. It has been accepted for inclusion in Genocide Studies and Prevention: An International Journal by an authorized editor of Digital Commons @ University of South Florida. For more information, please contact digitalcommons@usf.edu. 


\title{
Did Newsnight Miss the Story? A Survey of How the BBC's "Flagship Political Current Affairs Program” Reported Genocide and War in Rwanda between April and July 1994
}

\author{
Georgina Holmes \\ King's College London
}

At the time of the genocide in Rwanda in 1994, the BBC's late-night political discussion program Newsnight was one of the few media political spheres within which representatives of the British government, opposition parties, the United Nations, and international non-governmental organizations could comment on British foreign policy. Since 1994 the British media have been charged with failing to report genocide; yet a focus on print media has created a void in understanding how BBC's Newsnight covered events. The present article analyzes Newsnight reporting between 6 April 1994 and 30 September 1994 and reveals that the BBC framed the genocide in a specific way until 31 July 1994. A comparative reading between the discourse of presenters, guests, and the news reports filed by journalists reveals that, despite a stack of media evidence that genocide was taking place, no representatives of the British government or opposition parties were interviewed on the role of the UK as a permanent member of the UN Security Council and signatory of the UN Convention on the Prevention and Punishment of the Crime of Genocide from April to the end of July. Rather, a focus on the stateless "international community" and the failings of UN bureaucracy, the timing of debates, and the presenters' refusal to use the word "genocide" when guests and journalists did reveal that Newsnight failed to hold British politicians to account.

Key words: Rwanda, genocide, BBC, British media, war, democracy, British government

\section{Introduction}

In the years since the 1994 genocide in Rwanda, the British media have come under considerable scrutiny for failing to distinguish between government and Rwandan Patriotic Front fighting on the front line and the systematic killing that was taking place well behind government lines. By framing the killings as ethnic conflict and tribal civil war, the British media have been accused of contributing to the British government's disinterest in Rwanda and failure to meet its legal obligation as a signatory of the UN Convention for the Prevention and Punishment of the Crime of Genocide (1948). This accusation has been challenged by numerous journalists who seek to ensure that their version of events will go down in history. ${ }^{1}$ Former Africa editor for The Independent Richard Dowden has contended that Rwanda itself has

Georgina Holmes, "Did Newsnight Miss the Story? A Survey of How the BBC's 'Flagship Political Current Affairs Program' Reported Genocide and War in Rwanda between April and July 1994." Genocide Studies and Prevention 6, 2 (August 2011): 174-192. (C) 2011 Genocide Studies and Prevention. doi:10.3138/gsp.6.2.174 
"challenged assumptions and changed perspectives" about how the media should report on political crises in Africa. ${ }^{2}$ Dowden was responding to an article published in African Affairs by Linda Melvern and Paul Williams which argued that the British press may also have contributed to "a wilful policy of indifference and obstructionism by the British government." 3

There have been several studies detailing press coverage on Rwanda and questioning the extent to which the British media missed the story during the three months of genocide. ${ }^{4}$ A focus on the UK "CNN Effect" equivalent, which assumes that media coverage can influence government foreign policy, overrides discussions on the extent to which the British government dictated how the British media should frame events. In both academic and journalistic spheres, discussions have been limited in scope by an almost obsessive focus on broadsheet newspapers, at the cost of omitting television news programs. This omission is deeply unsettling, not least because, unlike printed texts which remain under tight editorial control, television news and political discussion programs provide media spaces within which political discourse is created and contested by multiple political actors simultaneously.

Perhaps more surprising is the absence of BBC's Newsnight from the discussion. Deemed an essential component of British democracy and renowned for its provision of in-depth analyses of political events and for holding to account those people responsible for them, ${ }^{5}$ Newsnight in 1994 was one of a limited number of media public spheres within which British politicians jostled to appear. Without the Internet and multiple television channels, Newsnight provided an opportunity for British politicians to promote themselves, their party politics, and their position on British foreign policy. They are joined by a host of experts who together contribute to Newsnight's political discourse.

The absence of any extensive analysis of Newsnight has led me to assess how the BBC current affairs program reported on the Rwandan Genocide between 6 April and 30 September 1994. A cross-examination of news features provided by journalists on the ground in Rwanda, media discourse generated by studio guests, and the debates set by editor Peter Horrocks raises questions about whether Newsnight had deliberately avoided using the word "genocide" and controlled studio debates in order to protect the interests of the British government. The present article addresses two aspects of reporting. The first part maps how and when political violence is referred to as genocide to suggest that there existed a conflict between the images and language in the news features sent by journalists in Rwanda and the spoken words of the presenter (or news anchor) during the program. The second part examines Newsnight's political discourse and studio debates. Until now, there has been no consideration of how political actors-including representatives of the UN, members of governments, NGO workers, missionaries, military operators, and civiliansmaneuver to influence BBC narratives about war and genocide in the region. An analysis of their political discourse, from which members of the British government are distinctly absent, provides a new perspective on the way in which the news anchors chose to frame events in Rwanda between April and July 1994.

A total of 29 Newsnight programs broadcast between 6 April 1994 and 30 September are analyzed. The corpus is based on a key-word search conducted by staff at the BBC Archives to identify Newsnight programs that contained news features on Rwanda during this period. These documentaries, in addition to all programs broadcast in April 1994, were viewed and transcribed at the British Film Institute (BFI) film archive in London in August 2007. 


\section{Newsnight's Institutional Framework}

First aired on Wednesday, 30 January 1980 with presenter Peter Snow, BBC's Newsnight aimed to provide an in-depth analysis of the day's news in a format that brought together the genres of television news and current affairs, which until then had been distinctly separate in British broadcasting. Founding editor George Carey enforced one rule stipulating that Newsnight should not lead on the same story as the BBC's Nine O'clock News. ${ }^{6}$ Newsnight would also contribute to the BBC's requirement to provide impartial coverage of news and current affairs. Today, as in 1994, Newsnight has a clear generic structure and has developed its own institutional framework for organizing media political discourse.

The Newsnight presenter uses conventions typical of political interviews and has a specific role to play in setting the agenda of the debate, questioning and challenging politicians, other representatives of the public, or lobbyists of governments and international organizations. News anchors such as Peter Snow, Jeremy Paxman, Sue Cameron, and Kirsty Wark, who all reported in 1994, adopt the generic identity of the Newsnight presenter to appropriate specific discourse traits and a tough questioning style. ${ }^{7}$ In addition to the political debates, each Newsnight program includes a series of extended news stories, often termed "news features" in the broadcasting industry, by documentary filmmakers and distributors. ${ }^{8}$ Between ten and twenty minutes in length, many of these short documentary films merge news and current affairs and often provide some form of historical background or evidence which is then debated in the studio.

The Newsnight formula and generic presenter persona have led some critics, such as New Stateman's Michael Leapman, to argue that the program's style leans too much toward "attack journalism" and focuses on creating rather than reporting, or indeed, analyzing news. ${ }^{9}$ Advocates such as former Economics editor Will Hutton believe that Newsnight, in enabling political discourse, provides "an essential aid to living in a democracy"; in 2002, he stated that the program was "one of half a dozen ... components now of actual British democracy and British citizenship."10 Former Director of Television Mark Thompson once described Newsnight as "the single most important program on the BBC." 11 The BBC boasts how over the years, the program has "broken countless stories, produced ground-breaking and policyshifting films," and "delivered many memorable interviews." 12

\section{Rwanda 1994}

On 6 April 1994, the plane that was carrying the Rwandan President Juvenal Habyarimana and President of Burundi Cyprien Ntariyamira back from Tanzania was shot down by missiles above Kanombe airport in Kigali just after 8 p.m. ${ }^{13}$ The presidents were returning from Arusha, where they had signed a UN peace agreement as part of the Arusha Accords which aimed to establish power sharing between the Hutu majority government and the Ugandan based, predominantly Tutsi-led refugee movement, the Rwandan Patriotic Front (RPF). On the ground, the UN Assistance Mission for Rwanda (UNAMIR) was led by Canadian Brigadier-General Roméo Dallaire who, under a Chapter Six mandate, was to oversee and monitor the Broad Based Transitional Government (BBTG). Within an hour of the plane crash, roadblocks were set up around the capital and mass killing on a scale that has not been seen since the Nazi Holocaust began. In the first forty-eight hours Hutu extremists, led by Colonel Théoneste Bagasora, undertook a military coup which saw the deaths of Hutu Power's political opposition, including the then interim 
Prime Minister and pro-democratic Agathe Uwilingiyimana and ten UN Belgian soldiers who had been protecting her. ${ }^{14}$ According to the UN, from April 6 to the end of July 1994, an estimated 800,000 people were killed, many within the first two weeks of the shooting down of the plane. The genocide took place four years into a war between the RPF and the former Mouvement Révolutionnaire National pour le Développement (MRNDD) government.

In the regions where genocide was taking place, witnesses spoke of neighbors killing neighbors but there was also a series of militias-Burundian Hutu refugees and the Hutu extremist youth-wing, the Interahamwe-who travelled from district to district killing and carrying out the most horrific human rights violations. During this period, an estimated 250,000 women, many of whom were Tutsi or had family members who were Tutsi, were raped. Civilian men and boys also suffered extreme gender-based violence and were among the first group to be targeted for death. In the first two weeks of genocide France, Belgium, and Italy sent troops into Rwanda under a national remit to rescue their citizens, but they were not under UN command. On April 11 the Belgian peacekeepers began to pull out and by the end of the first week of genocide and war, the US, France, and Belgium had closed their embassies. On April 21, the UN Security Council passed Resolution 912-its first since the beginning of the genocide-to withdraw the majority of peacekeepers and retain a small contingency.

Throughout April, France cautioned the international community against an intervention that would mean taking sides against the extremist Hutu government. There was a reluctance to refer to the violence as genocide, with Britain and the US being among the most vociferous in avoiding the term. On April 29, Czech Ambassador Karel Kovanda, alongside Colin Keating, called for the UN to officially recognize genocide in Rwanda. ${ }^{15}$ British Ambassador David Hannay claimed that if the UN used the word genocide in official documents, the Security Council would become a "laughing stock." 16 According to Melvern, British representatives, renowned for their ability to frame "resolutions with mind-numbing ambiguity," played a direct role in crafting a statement taken from the Genocide Convention, objecting to "the killing of members of an ethnic group with the intention of destroying such a group in whole or in part," arguing that such a crime, although not directly called genocide in the statement, would be punishable under international law. ${ }^{17}$ By the beginning of May, Sir David Hannay argued that the Organization of the African Unity (OAU), which had put pressure on securing the peace agreement from 1990 onward, had a "key role to play" in halting the violence. ${ }^{18}$ It was not until May 13 that Secretary General Boutros Boutros-Ghali suggested to the UN Security Council Dallaire's proposal to send in an additional 5,500 troops. ${ }^{19}$ There followed hours of discussion behind closed doors before a public debate on May 17, whereupon it was agreed that an additional force was required. Resolution 918 was passed, which recognized that UN troops may be required to use force to protect civilians. No troops were made available and both the UK and US believed that there should be a clear mandate for military operations, but member states did not put forward the funds or military personnel requested by the UN. ${ }^{20}$

Throughout May, Dallaire retained a voluntary force of some 350 men, despite having been called to withdraw the troops early in April. From mid-May onward, debates in the Security Council focused on the need to extend UNAMIR's mandate to military intervention. By June 17, as the MRNDD government and the extremists were retreating westward into Zaire, France put forward a proposal to deploy French 
troops under a humanitarian mission Operation Turquoise. The Security Council endorsed this proposal on June 22 in Resolution 929. The operation was met with criticism by the British media and it was widely held that France was trying to retain its francophone influence in the region.

\section{Genocide or War? Newsnight's Silenced Debate}

"Genocide" was first coined by Polish lawyer Raphael Lemkin to describe the politically sanctioned annihilation of targeted civilian groups outside of the context of war. Under the United Nations Convention for the Prevention and Punishment of the Crime of Genocide (1948) genocide constitutes the "intent to destroy, in whole or in part, a national, ethnical, racial, or religious group." 21 The Convention was established out of recognition that the newly ratified Crimes against Humanity perceived national sovereignty as sacrosanct. At the time, under international law, states and individual perpetrators who acted within the boundaries of those states could still freely commit genocide unless they did so across national borders. ${ }^{22}$ The UN stipulates that nation states that have signed the Convention have a legal responsibility to act to stop genocide and to hold perpetrators to account.

Since 1948 it has become apparent that the extent to which those UN member states halt genocide rests more on political will than any acknowledgement of legal responsibility. It is for this reason that using the word genocide in news stories and political discussion programs that report on political violence is considered so important. Accordingly, Newsnight, considered a central component of British democracy, should at most challenge the British government and opposition parties to ensure that the UK, as a signatory of the Convention, fulfills its role in preventing and halting genocide. However, an analysis of Newsnight programs broadcast between 6 April 1994 and 30 September 1994 reveals that the British government is not challenged throughout the course of the genocide.

In the first days of the genocide, Newsnight's coverage of political violence in Rwanda is generated within the studio and completely controlled by the editor Peter Horrocks. The first story is provided on the day after President Habyarimana's plane was shot down, Thursday, 7 April 1994, when the following is mentioned by presenter Peter Snow in a single-sentence story during the summary of the day's news: "eleven Belgian troops serving with the UN have been killed in fighting in the central African Republic of Rwanda."23 The following day, Rwanda is mentioned in the summary news by Kirsty Wark, who announces that the central African state is "in a state of anarchy tonight" and that "thousands of people have been killed during two days of ethnic violence in the capital Kigali." 24 In addition to using the ethnic conflict/coming of anarchy framework of reporting, Wark refers to the history of colonialism by honing in on the actions of the Belgian government who is "making plans to fly its nationals out of the country," although no effort is made to describe the political history, which includes the genocides of 1959,1963 , and $1972 .{ }^{25}$ Visual images portray both militarization and humanitarian catastrophe: we see soldiers chanting and raising their guns in the air followed by pictures of refugee camps and people-mainly women-huddled in makeshift temporary huts. According to my research, in the first nine days of war and genocide, Rwanda received a total of 2 minutes and 50 seconds of coverage on Newsnight. Comprehensive reporting on the country does not occur until almost a month after the genocide began when, on 4 May 1994, we are presented with the first news feature. 


\section{Using the Word "Genocide"}

Overall, news features vacillate between describing political violence as "civil war," "ethnic war," "ethnic cleansing," and "genocide" in all its clarity. However, an analysis of Newsnight programs reveals that the word genocide was only mentioned five times between 6 April 1994 and 27 July 1994, before the RPF claimed victory and declared a unilateral cease-fire. Newsnight presenters refer to the term just three times and only after the US and UK recognize the new RPF government at the end of July. Genocide is first mentioned by reporter Tom Carver in a news feature broadcast on May 16: "Everyday, evidence of the genocide inside Rwanda washes up at this outpost." 26 His statement is not echoed by presenter Sue Cameron who uses the ethnic conflict/coming of anarchy framework of reporting: "As the killings continue in Rwanda's civil war, most of the dead are members of the minority Tutsi killed by government supporting Hutus." 27 The word genocide is not mentioned again until June 20 by expert Ian Lindon from the Catholic Institute for International Relations in his second appearance on the show since the plane crash. Lindon argues that French intervention to create a humanitarian zone in the west of the country and a UN brokered cease-fire agreement will not stop the killing because it is state-led political violence and a deliberate targeting of a particular civilian group:

One of the sides - the Interim Government - has been guilty of genocide. The other side, the Rwandan Patriotic Front, has done more than external agencies to free people and to rescue their kith and kin. To consider a ceasefire at this point would simply be to allow the killings to go on because it is not primarily regular armies that are doing the killing, it's the Hutu extremist mobs. ${ }^{28}$

Ignoring Lindon's reference to genocide, Peter Snow continues the debate on whether France should intervene in a pre-recorded (and therefore controlled) interview with the General Secretary of the RPF, Dr. Theogine Rudasingwa, who refers to the "people responsible for genocide" three times. ${ }^{29}$ Rudasingwa talks about the "people who definitely have carried out and planned the genocide" on July 4, the day when the RPF took control of Kigali and declared it will establish a new government based on the Arusha Accords, but again, this is not picked up on and debated by presenter Sue Cameron. ${ }^{30}$ Later on, on July 15, Robin Denselow in his second news feature for Newsnight since the genocide began, reports exclusively on the shooting war, although his introduction makes it clear that genocide was taking place: "They've captured the capital and now the rebel troops of the RPF are poised for the final battle for Rwanda. It's been an extraordinary victory, but can they really bring peace to a country divided and wrecked by genocide." 31 Denselow is practically ignored by Paxman in the studio, who relies once more on the ethnic conflict/coming of anarchy framework of reporting to emphasize the importance of a cease-fire.

It is not until 27 July 1994, when both the US and UK officially recognize the new RPF government, that the word genocide is mentioned by a presenter when Kirsty Wark hosts a Newsnight Special debate on Rwanda. Although this is the first time a news anchor utters the word, Wark continues to use the ethnic conflict/ coming of anarchy framework of reporting, thus suggesting that the targeting of civilians was degenerative in a backward, "African" kind of way. One month later, on August 25, Kirsty Wark, echoing Martin Shaw's concept of degenerative war, declares somewhat inaccurately that "civil war turned into genocide." 32 Newsnight only begins to use the word genocide continuously from 22 September 1994 onward, in sync with the UN. During this September broadcast, Jeremy Paxman introduces 
the headline story in a manner which criticizes the UN, even though Newsnight (and the $\mathrm{BBC}$ ) played no role in pressuring the UN into acknowledging that genocide was occurring from April onward. Paxman declares, "A United Nations investigation has at last given slaughter in Rwanda the name it so long seemed to merit: it was genocide." 33 This statement is qualified by Robin Denselow's news feature wherein he reports that the "UN is under attack in Africa for taking so long in bringing those responsible for genocide to justice." 34 In the first three months of reporting since the plane crash, journalists in the field and guests on the show refer to genocide, while Newsnight presenters avoid using the word.

\section{Describing the "Act of Genocide"}

Agence France Presse (AFP) reporter Anne Chaon has argued that journalists are obsessively preoccupied with their failure to properly describe political violence in Rwanda following the shooting down of President Habyarimana's plane. "Most journalists," she writes, "are not expert in genocide. Many of them, myself included, arrived in Rwanda with very little knowledge of the country." 35 As a consequence, war was described more often than genocide. The problem of describing political violence in Rwanda is expanded upon by BBC correspondent Mark Doyle, who spent a significant amount of time in the first three months after the plane crash filing stories from Rwanda. Doyle claims to have reported two types of conflict: the "shooting war" and the "genocide war," but observes that he did not use the actual word genocide until April 29 in a report which referred to British aid agency Oxfam's announcement that genocide was taking place. ${ }^{36}$ Doyle has since admitted that in the first weeks he got the story "terribly wrong," in spite of having been briefed on the political situation in Rwanda by the ambassador of the African Embassy in Kigali in early $1994 .{ }^{37}$

Like Chaon, journalists who were reporting in Rwanda alongside Tom Carver at the beginning of May have expressed their difficulty in knowing how to recognize genocide as something distinguishable from war. Australian Broadcasting Corporation (ABC) British journalist James Schofield, who met the BBC Newsnight team outside the gates of the interim government's temporary headquarters in Giterama (its members having fled Kigali the month before), felt that his own coverage was flawed. Schofield had missed the start of the genocide, had not been engaged, and later found it difficult to gain entry into Rwanda. When he did travel into the interior from Burundi's capital, Bujumbura, Schofield kept hearing stories of widespread massacres but could not see any bodies, in part because the perpetrators had concealed them. Schofield felt that it was challenging for journalists on the ground to comprehend what was taking place, claiming that "you do have this blind spot about genocide - it's jolly difficult to imagine it." 38

Other journalists who reported in Rwanda at the time felt, retrospectively, that the difference between genocide and war was distinct. Geoff Adams Spink was a producer for the BBC Radio Four Today Programme in May 1994. Having some interest in Burundi, Spink approached his editor Roger Mosey for permission to travel to Rwanda from the UK. His editor agreed, provided that he report only from the borders of neighboring countries and not enter into the interior. Spink notes that his brief was to report on the refugees and the tensions because they had similar ethnic tensions in Burundi. ${ }^{39}$ While in Tanzania, Spink was reliant on conversations with NGO workers for information but they were only providing stories about what Spink terms "the human migration fall-out." 40 Upon spending four days in Burundi, Spink, broadcaster Andy Kershaw, and another journalist secured an accompanied 
journey into Rwanda with an RPF guide. During his three-day trip, Spink indicates that while in Rwanda he saw both war and genocide, but confusion lay in understanding what atrocities were taking place in the war zone and what was taking place behind government lines (i.e., in the areas where genocide was continuing):

We saw both ... front lines are not demarcated nicely with white picket fences ... they are very fluid places. I think we'd happened upon the frontline when even the $[\mathrm{RPF}]$ officer who was escorting us believed that we were well behind it. But the distinction to me is that ... five minutes before the landmines and the ambushes started to happen, we stood on the bridge of the river with a detachment of RPF troops and they pointed down and literally once every thirty seconds - and we timed it - literally once every thirty seconds there was another body floating down the river and it was usually civilian. No. it was exclusively civilian. Usually older people, children, women - hands tied behind their backs, floating with their face down. Now that's not war, that's genocide as far as I'm concerned. In the same way that the trashed village had the bodies of all the villagers stuffed down the village well. And again, that's not war, that's genocide. It's the same with what we saw in Nyamata, so that was genocide. And then we happened upon war as well. ${ }^{41}$

Concerned that Newsnight was too dependent on rehashing the pieces that BBC news was delivering, producer David Belton sought an agreement from Peter Horrocks to report on Rwanda in late April 1994. Like Spink, Belton's brief was to cover the refugee crisis that was building up in Tanzania and he was told to stay outside of Rwanda's borders. Alongside a sound technician and cameraman, Belton arrived in Kenya on April 25 and travelled by car from Nairobi to Boneo camp in Tanzania with BBC World Service correspondent Tom Carver, who had recently reported from Johannesburg. The Newsnight team shot its first news feature on those borders, where they encountered the RPF at Rusumo Falls before returning to Nairobi to cut the film. Like Spink, Belton knew that they were witnessing genocide but concedes that the first film was not explicit enough:

It wasn't that we didn't think it was genocide - we couldn't say with certainty standing on the border. It was a difficult position to be in. It was complex in terms of what we were seeing and what we were hearing. If we had been standing on a live wire to Paxman and were asked were we seeing genocide, we couldn't say yes. [In that first film] there should have been a line saying this is what people inside the country are saying. We made amends in the second one - no one else had been to or seen Kabgayi. $^{42}$

In another parallel with Spink, the team rebelled against the instructions of Newsnight management and travelled into Rwanda from Bujumbura. A priest from the former Yugoslavia, Vjeko Curic, was running an ad hoc aid mission into the country. Curic would not let them ride in his lorry, and agreed instead that they could tailgate him to Kabgayi, located well behind the extremist government lines and known to the Red Cross as a place where systematic killing was taking place. Belton believed that they saw genocide but at the time found it challenging to depict on camera:

Yes, I believed we were witnessing genocide. It was complex - you saw it in various ways but not on camera - that was switched off. We knew it was genocide as there were people lying on the side of the street in large numbers. Some were butchered in front of us and we saw the process happen. There was one man with pink identification papers - we saw them. It was very difficult to tell people this or visualise it for people - we didn't do a good job in conveying what we'd witnessed. The camp was 
more complex because they [the Tutsi] were alive. Soldiers were walking in and out. There was a Red Cross presence and therefore it was very difficult for the Hutu soldiers to wipe out this particular group of people. The Bishop was high up in the political hierarchy of the country but at the same time he was a bishop. The killing was not something the government wanted to see themselves and at the time they were under heat from the international community. The camp was just off the main road, it was one month after the genocide had begun and they were several leagues behind the front line - it was difficult for the government to call it civil war, which is what they were saying... The people in the camp were slowly starving to death and were being pulled out. A lot of young women I think lost their lives. It felt like a death camp in a Bosnian war - only more brutal. ${ }^{43}$

Journalists in the field and distributors of news features were aware that the story was big. Ron McCullagh, director of the documentary film production company Insight News TV based in London, distributed for journalists Catharine Bond, Nick Hughes, and Lindsey Hilsum during the genocide. It was in his company's interests to rally broadcast new editors into purchasing footage. Insight News TV had hours of rushes provided by Catharine Bond but no polished documentaries. From April to June 1994, Insight News TV distributed footage to Germany, Spain, and Canada, among others. But there was little interest in the UK. McCullagh recalls,

We faxed people around the world and we said this was happening, could you possibly send us your interest and we'll send you some material. Part of the problem was that the material was unprocessed. Normally this is a company that produces and makes films ourselves and so normally they get a finished piece. In this particular case, we couldn't do that because Catharine was on the road and filming all the time and what finished pieces she was doing, she was doing directly for Channel $4 .{ }^{44}$

For McCullagh, there was a sense that the editors had already decided not to run the story. Although he admits that his team did not explicitly use the word genocide, Insight News was stressing that the level of violence was extreme and more than a typical African civil war scenario:

This company has a reputation for dealing with stories around the world and therefore not the stories that are high up on the agenda, and we are careful about the people we work with in order to protect that reputation. So there is never a question of the veracity of our material. It's down to whether it's important enough to get on the news bulletin from where the editor stands.... We tell them the story, they don't respond. Then we come back and tell them look, it really is a story. They still don't respond. Then we go back and say look this is really serious. At which point, they close down. And they think "well you're pestering." They've already made their decision. ${ }^{45}$

\section{Describing Genocide}

If media institutions are expected to monitor political violence and assess whether genocide is in process, the question might focus on what evidence should be mediatized. Genocide scholar Helen Fein's paradigm is apt for assessing the extent to which evidence of genocide was present in Newsnight news features. Fein identifies five conditions which constitute genocide: evidence of a sustained attack on a selected group; evidence that the perpetrator is part of an organized group, often led by a commander; evidence that victims are targeted because they are members of a certain collectivity as defined by the perpetrators; evidence that victims are defenceless; and, finally, evidence that an intent to kill is sanctioned by the authorities. ${ }^{46}$ As 
Belton suggests, within Newsnight news features there is evidence of all of these conditions in Rwanda, most notably in the documentaries shot in early May 1994. For example, in the news feature broadcast on May 16, Carver interviews Vjeko Curic, who reports, "The Tutsi I've met so far, those left behind, are just waiting to be killed. ... They don't know how to get out of the situation, and most of them think they will be killed. They are just waiting to die." 47

In the same news feature, Carver observes that the authorities are both condoning and instigating the targeting of civilians. Here, it is worth quoting the documentary at length, since it demonstrates a logic of reporting based on the distinction between war and genocide:

Most ordinary people are struggling to continue their lives amidst the carnage. But they're being bombarded by extremist propaganda on the radio, urging them to keep killing their Tutsi neighbours and every so often we would get a glimpse of the horror that lay beneath the surface. Yesterday, as we were waiting at this spot to be led into the Seminary [the camp at Kabgayi], we watched a man being interrogated by soldiers. With his hands tied behind his back, he knelt in the dirt pleading his innocence. Suddenly, the soldiers handed him over to a group of civilians who clearly wanted to kill him.... All this took place in sight of the Bishop's palace. This is a country where all moral order seems to have been destroyed.

The UN may be trying to stop the war between the government and the rebels but that's not where most of the atrocities are occurring. They are taking place in remote villages deep inside the government controlled areas, far away from front lines and foreign eyes. ${ }^{48}$

The challenge in describing genocide is also evident in their news features. On May 10, Carver states, "You cannot explain this as just a tribal conflict. At an ordinary human level, Hutus and Tutsis have lived easily together, so much so that it's hard to distinguish one from another." 49 Instead, the Newsnight team borrows from documentary film representations of the Nazi Holocaust to reproduce visual representations of genocide that would have been familiar to a British audience at the time. Carver uses the language of the Holocaust to describe the death camp-labelled a refugee camp - wherein Tutsi are selected to be taken away and killed by Interahamwe and government soldiers. "These people are caught in a terrible dilemma," Carver says, "it felt as though we'd entered the Jewish ghettos at the height of Nazism." 50 Here, camera shots echo the scenes of the Nazi concentration camps, first honing in on people in the background, then focusing on a baby crying and a frail old woman resting her head against the wall, before readjusting the focus of the camera on to the wire fence in the foreground. The documentary then cuts to a hand resting on the wire, before the scene pans out to see more children standing behind the wire.

Witnesses provide the most graphic accounts, but it is clear that they are unable to adequately describe in words what they saw. Missionary Rob Wilson, interviewed by Tom Carver for the May 10 news feature, recalls,

As a Christian, I can't understand how a normal person would take up a panga (machete) and er ... just kill an innocent baby or a child or a mother.... And so something snapped inside these youths or whoever did the killing ... that made them do things that were unthinkable. It's just not normal. I mean, you can understand in a war situation, soldiers shooting each other but innocent people that had no political affiliation - they were just children and so on ... you just can't ... I just can't imagine ... something gripped the people who were committing these massacres and it's difficult to explain it in human terms." 51 
It is also clear that members of the Tutsi population are being singled out. On May 16, Tom Carver interviews Swiss businessman Claude Sonier, who was trapped in Butare with his Rwandan wife and children before being rescued by an Italian consort and is now in Burundi. It is quite clear that Sonier is deeply traumatized by what he has seen, and Carver weaves his words into a narrative that sensationalizes the horror of the journey into Rwanda on which they have only just begun to embark:

Tom Carver: He told us that hundreds of people, including his wife's mother, had been thrown alive into a pit full of burning tires.

Claude Sonier: Forty percent of the population is dead today. Forty percent! Because you have not so much Tutsi in life today.

Tom Carver: You talked about a big pit. Can you just describe this please?

Claude Sonier: No! No, it's too much [shaking his head] ...

Tom Carver: As he was leaving he gave a chilling warning of what lay ahead.

Claude Sonier: Sa mère, son frere sont capité. Un vieux - coupé en quarters. ${ }^{52}$

While at Kabgayi, unarmed civilian Rwandan Tutsi boys who are interviewed by the Newsnight team also find it difficult to explain the horror they face:

Tutsi boys [translated]: They are attacking us. It's unbelievable. They come in here and take the old and the young out of the camp and kill them using knifes and machetes. It defies imagination and there's nothing we can do.... All the people they target are Tutsi. They don't want us to live in this country any more. ${ }^{53}$

Fein indicates that this inability to describe genocide is common among first-hand witnesses and was just as notable during the 1915 Armenian Genocide when reports by foreign correspondents, missionaries, travellers, and diplomats were sent from Turkey to London and America. Fein notes that these observers knew that horrors and crimes were taking place, and "words such as 'atrocities,' 'extinction,' 'extermination,' and 'perished' were reiterated," but nothing with as much as the legal term or concept of genocide. ${ }^{54}$ In the case of Newsnight reporting, "horror" becomes the most frequently used word by both journalists and witnesses to describe what they saw. If journalists, witnesses, and those about to be killed cannot find a word suitable for the crime, we are left wondering who in media institutions is responsible for identifying genocide amid such a stack of media evidence.

\section{Studio Debates}

Since Newsnight prides itself on its ability to challenge politicians on behalf of British citizens one might ask, what was the political discussion program's approach to engaging representatives of the British government, a permanent member of the UN Security Council, in studio debates when its very own news features provided evidence of genocide in Rwanda? In this regard, how were studio debates framed to allow for taking those in power to task?

On May 4, Rwanda is described in sensationalized terms by presenter Sue Cameron who states that the "horror worsens" before questioning "what the UN should do in Rwanda. Can intervention stop the bloodshed?" 55 This first debate sets the scene for many repeat discussions between May and July 1994 about whether or not the UN (but not UN member states) should intervene in Rwanda. Each time, the angle of the story changes slightly but the issue on the agenda remains the same. On 
10 May 1994 Newsnight questions the role of US intervention in Rwanda, with presenter Peter Snow describing two situations: civil war and humanitarian crisis (refugees are fleeing), and the West having problems delivering aid to them. ${ }^{56}$ Civil war dominates the next debate on May 16, the same day that the UN votes to send 5,500 troops to Rwanda and Carver's accompanying news feature portrays images similar to those of the Nazi Holocaust. The following day, concern is expressed for "world failure" in stopping war generally, and the "tragedy of Rwanda" as the "most recent" war becomes the case study in which to frame a discussion led by Jeremy Paxman on the role of the US in "gearing [UN] member states into action," although member states are not singled out. ${ }^{57}$ Six days later, on May 23, Newsnight reports on the UN's failure to "broker a ceasefire" and asks "what should [the then Assistant Secretary-General in the Department of Peacekeeping Operations] Iqbal Riza do next?" placing emphasis on UN bureaucracy and the role of international civil servants. ${ }^{58}$

On June 20, the issue on the agenda concerns France's decision to send in its own troops on the humanitarian mission Operation Turquoise, and Newsnight asks "should France go in." 59 On July 4, Newsnight reports the victory of the RPF, stating that "the victorious Rwandan Patriotic Front find their advances blocked by France" before questioning "are French motives purely humanitarian and will it come to open battle between French and Rwandans?"60 Eight days later, on July 15, Newsnight continues to report on the civil war, heralding that a cease-fire is "imminent" before discussing the exodus of refugees fleeing into Tanzania. It is not made clear that these refugees are Hutu, some of them perpetrators, fleeing the advances of the Rwandan Patriotic Front. Attention returns to the role of the world in saving refugees from the "latest horror" on July 18 and 22, when again Rwanda serves as a case study for discussing whether the West "really know[s] best" when dealing with humanitarian crises. ${ }^{61}$

All of these debates are confined to the realm of international politics and international organizations (in particular the UN), which are imaged as detached from domestic UK politics and British government foreign policy. Newsnight avoids discussing the British role in influencing UN decisions around military intervention. Not once throughout the course of reporting on Rwanda does Newsnight refer to the lobbying efforts of the political activists and NGOs that urged the UK government to recognize that genocide was taking place. In late April, when Rwanda is absent from Newsnight's agenda, Amnesty International, Human Rights Watch, and Oxfam publicly demanded that the British government take immediate action in the interests of Rwandan civilians. ${ }^{62}$ On Tuesday, May 3 David Bryer, the director of Oxfam, and British actress Helen Mirren presented a petition and accompanying letter to the then Prime Minister John Major at 10 Downing Street stating that genocide was taking place. ${ }^{63}$ On the following day, May 4, Oxfam printed an advert in The Times, labelling the violence in Rwanda genocide-but arguing that genocide was something extreme, greater than war-and the deliberate targeting of civilians. Below the image of piles of skulls the caption reads,

After Cambodia the world said: "Never again," yet in Rwanda there is genocide. Oxfam does not use the word genocide lightly, but there is no other way to describe the mass slaughter happening right now. Men, women and children are being systematically hunted down, tortured and killed. The rivers are choked with bodies.... Half a million people, mainly Tutsis, face imminent death. ${ }^{64}$ 
Oxfam appeals directly to the British government: "What is happening in Rwanda is a crime. The apathy of the world is criminal. We believe Britain must use its seat on the Security Council to call for effective UN intervention in Rwanda, now."65 This political activism is not included in Newsnight's analysis of the day's news. Instead, on the day that Oxfam prints the advert, Newsnight begins its two-month-long series of debates on the role of the international community, the need for a world leader in gearing nation states into action, and criticism over the ineffectiveness of the UN. From the start of the genocide until the end of July when the RPF took control of the country, no British MP from any of the parties and not a single member of the British government is interviewed by Newsnight, in spite of the importance of the program in 1994, at a time when there were less media public spheres and less opportunities for political actors to promote themselves and their parties. Interestingly, the first MP to speak on Newsnight is interviewed on July 22 during Newsnight's declaration that America has "seized the initiative ... to counter the crippling epidemic" in Goma refugee camps in Zaire. Long-standing Conservative MP Toby Jessel chooses to hone in on the humanitarian refugee crisis to commend both the US and UK for funding aid agencies and the UNHCR (United Nations High Commissioner for Refugees): "If every country had responded as well as the Americans and the British," he states, "the problem wouldn't be as grave as it is." 66

Once the RPF declared victory on July 22 and was recognized by the US as a legitimate government, representatives of the British government began to appear more frequently on Newsnight. However, an analysis of the Newsnight Special broadcast on 29 July 1994 and a close examination of the political discourse generated by numerous actors during the studio debate suggest that Newsnight reporting ensured, above all, that the interests of the British government were protected.

In the hour-long extended program, Kirsty Wark hosts a chat-show style debate to examine the "developing crisis in Rwanda." Baronness Lynda Chalker, the then Minister of State for Overseas Development at the British Foreign Office, is the special guest in the studio. She is joined by Rwandan Tutsi Joseph Mutabobo and Rwandan Hutu Ally Yusuf Mugenzi, Rakiya Omaar of Africa Rights, former British Gulf Commander General Sir Peter de la Billiére, former director of War on Want George Galloway, war crimes expert Dr. John Pritchard, Stuart Wallis of Oxfam, Ali McHums of the Tanzanian High Commission, BBC World Affairs editor John Simpson, Conservative MP Nick Budgeon, and Great Lakes scholar Filip Reyntjens. US Special Envoy to Rwanda Brian Attwood, Archbishop Desmond Tutu, the UN's Iqbal Riza, the UNHCR's Sylvanna Foa, Dominique Moisi from the French Institute of Foreign Affairs, and RPF representative Dr. Rudasingwa-many of whom had already appeared on Newsnight over the course of April, May, and June-appear on the show via satellite link-up. The program includes a news feature by reporter Robin Denselow in Goma and a "personal argument" by John Simpson. A series of debates construct an overall story of events from, as Kirsty Wark describes in her introduction, "the roots of the killings, the international response and its failures, what the UN can deliver and the agendas which govern the West's dealings with post-colonial Africa."67 The role of individual nation states is barely discussed and Britain is imaged as trying to prevent crisis in Rwanda from April onward.

Wark does well to avoid challenging Chalker about the role of the UK as a permanent member of the UN Security Council. However, Chalker, introduced as having just returned from Rwanda (and therefore appearing to be heavily involved in the crisis), claims that "Britain has been helping in Rwanda since the beginning 
of April" before suggesting that the UK is itself powerless because other factors prevent an international response. Chalker states,

We've already spent over $£ 50 \mathrm{~m}$ in this crisis. We have a large number of soldiers, we all know in other places, but we have said we would help in the way that General Dallaire has requested of us and we've fitted exactly what he needs. We were not able to do so in May but it was generally agreed in the OAU that African forces would go in. There has been a real difficulty I think in procurement, not only of forces, but equipment, to allow them to be deployed. And that is something that the UN has really got to put right. ${ }^{68}$

Wark then turns to Rakiya Omaar and asks whether the UN's role, as Chalker says, has been good enough. Omaar refers directly to the UN as having "completely betrayed the hopes of the Rwandan people." 69 Emphasis on the role of a seemingly independent United Nations, existing outside the control or influence of member states, is challenged first by Andrew Wallis from Oxfam, who makes the point that General Dallaire and his small number of forces "have done their best" but have been let down by the international community who "did not do enough to get 5,500 troops in."70 Wark turns to Archbishop Desmond Tutu to qualify that it was not just a "Western failure" to act, thus detracting from a potential focus on the role of the British government in providing troops. The Archbishop is the first person on the program to refer to the "Rwanda crisis" as genocide, claiming that "governments could have responded much earlier ... to stop the genocide." 71 This statement provides a platform for the then Assistant Secretary-General in the Department of Peacekeeping Operations, Iqbal Riza, to cleverly expose the inaction of the member states, in particular the UK:

Well I think Arch Bishop Tutu has already spoken for us [i.e. for the UN]. Indeed there were troops on the ground, as Baroness Chalker says, but with all due respect to her, those were troops that did not belong to the United Nations and the countries who had contributed them immediately decided to withdraw them. Within a matter of a couple of weeks, we were down from 2,500 to 250 because governments decided to withdraw them and because the Security Council itself decided to reduce the force. There was a certain reason. The governments who had sent those troops had sent them for a certain mandate, which was to help the parties to implement the agreement, which then broke down. They were not willing to leave these troops in the condition when these massacres and the civil war resumed. One has to say that the very fresh experience of Somalia was hovering in the background-the ghost of Somalia, and that I suppose influenced governments. But as Arch Bishop Tutu has said, the capacity, the potential, was there. It was not simply an African operation. The west is very much a part of the United Nations and it has demonstrated that when the will exists, they can deploy. The French deployed in a matter of days. The Americans have deployed in a matter of days. And Baroness Chalker is right. The British have offered a unit just during the last few days, and it will be there in the next few days. ${ }^{72}$

In closely analyzing the dynamics between Baroness Chalker, Brian Attwood, and Iqbal Riza, we perhaps have some insight into the tensions between member states and UN bureaucracy. Riza's comment on the situation is quickly derided by US Ambassador Attwood, who himself uses a number of tactics to divert attention away from individual member states. First, Attwood contends that debates around the responsibility of individual governments are "not particularly constructive," since "if we blame the United Nations, we're blaming ourselves."73 In seemingly speaking on behalf of the public, Attwood's use of rhetoric moves the audience away from 
thinking about the crisis in terms of genocide and toward viewing it as chaotic ethnic war and he cleverly distinguishes between "irrational" African politics and "rational" Western politics. At the same time, Attwood argues that we (that is, we in the "West") must distance ourselves from what has already happened so that the entire world can examine the crisis. It seems that Attwood subtly calls for the kind of distance that only the passing of time can bring, thereby arguing that what has happened has happened and there is nothing we can do now. Here, it is worth quoting his discourse in full:

I don't think this debate is particularly constructive, frankly, I think we have a serious problem in dealing with these kinds of conflagrations. The world itself must examine this situation as a case study. It's a very emotional situation because so many people have lost their lives. But we should be realistic here. What has happened is that we were faced with the need to place troops in the midst of a hot civil war. It's very rare that you will find the political will to do that. It seems to me we need to look-not blame-the United Nations. Indeed, it is true we are all part of that. If we blame the United Nations, we're blaming ourselves. We have to look at our capacity to respond to these things. It's a much more constructive debate it seems to me, if we can examine whether or not there was a way to prevent this crisis from happening in the first place. These irrational forces at play. We're now looking back with 20/20 hindsight and expecting to come up with rational answers. It's easy to do in hindsight, as opposed to on the spot. ${ }^{74}$

Later, Attwood uses similar tactics to distance the US from the responsibility of making political decisions about whether to intervene (to stop genocide), announcing that, with the RPF government in place, the US "will be putting two hundred people on the ground in Kigali" as part of a humanitarian mission. "Everyone has to play their proper role," Attwood concludes, "I think that's the role we define ourselves."

\section{A Public Relations Exercise?}

In addition to its focus on UN bureaucratic failure, Newsnight's extended debate also appears to whitewash events in order to further dumb down public questioning of British foreign policy. This is most noticeable in the discourse of Conservative MP Nicolas Budgeon, who contends that the British government will only act to prevent political violence or war abroad at the behest of the British public. When asked by Wark whether the Organization of the African Unity (OAU) needs more help, Budgeon appropriates an argument that had previously been used to challenge nation states on their failure to act to prevent genocide and then subverts it by reminding the audience that domestic priorities must come first. In doing so, Budgeon taps into both the fears and needs of the average British citizen, or perhaps the average viewer of Newsnight in 1994:

The so-called international community doesn't have a budget and doesn't have any money ... it is all about political will. What this boils down to is whether there is a national political will. And in this instance, I don't find people coming up to me in the streets and saying "I'd like my son to go and fight in Rwanda and run the risk of being killed." Nor if you ask them "are you in favour of a lot of money being spent there" are they prepared, for instance, to delay the start of a new hospital so as to aid in Rwanda. ${ }^{75}$

As part of the program, BBC World Affairs editor John Simpson provides a personal commentary. Filmed in an editing suite, Simpson considers why it was that the international community neglected Rwanda. Simpson appropriates the "balance of 
power" image of politics to contend that during the Cold War "no one hung around waiting for a public reaction" and states that nations have "cut back on long-term development aid"76 to focus on short-term relief. Simpson concludes his "expert" analysis by arguing that "public opinion's only aroused once the crisis point has already arisen." The inclusion of Simpson, as the BBC's World Affairs editor, masks Newsnight's own failure to extend its "in-depth political analysis" to challenge UK politicians during the three months of genocide. And it is quite ironic that Newsnight now discusses the need to rouse public interest in order to ensure that governments act, when the program itself failed to report on the British public's interest in Rwanda in early May.

\section{Conclusion: Newsnight's Denial}

Fein has argued that denial can take many forms and includes a failure to recognize an event as genocide at the time. ${ }^{77}$ Policy elites of allied states have a political interest in denying genocide in order to demonstrate loyalty or allegiance to the country or allied countries that are closely connected to the state committing genocide. It has been suggested that Britain's engagement in politics of revisionism at the time stemmed from a loyalty to France: an early Freedom of Information (FOI) request to the UK Foreign Office in 2005 for information on Britain's knowledge of genocide at the time was rejected on the grounds that it would compromise Britain's relationship with France. ${ }^{78}$ Fein indicates that governments and elites often adopt various framing devices to confuse public opinion. My analysis of Newsnight suggests that between April and the end of July 1994 the program did well to convey a sense of confusion, off-setting media evidence of genocide in the news features with sensationalized statements by news presenters to the contrary and confining debates to brokering a UN cease-fire and the bureaucratic failings of the UN. Newsnight's control over studio discussions and its reluctance to add to its media agenda the obvious debate-is this war or genocide?-between April and July 1994, followed by the sudden appearance of members of the then Conservative government once the RPF had taken control of the country are both particularly striking.

In failing, and quite possibly deliberately avoiding, to use the legal term genocide, the Newsnight team was not obliged to follow the BBC's own mandate of aggressively interrogating British politicians. Rather, the presenters are seen to be aggressively interrogating a host of international politicians who themselves make no reference to Britain's status as a permanent member of the UN Security Council. The tactic of avoiding British influence in international politics is strengthened by an alignment to the frameworks propounded by Samuel Huntingdon in his Clash of Civilisations and Robert Kaplan's The Coming of Anarchy, which assume there is a morally constituted "international community" to police world politics from which Britain appears to be decidedly absent. ${ }^{79}$

The continued ignorance of Britain's citizens of the decision making of British government representatives such as Lord Hannay and Linda Chalker during the Rwandan Genocide is endemic of British foreign policy. Melvern asserts that the UK's foreign affairs are the "most private realm of political affairs in the UK" and that "there is a governance which is unaccountable and does not have parliamentary oversight." 80 Melvern and Williams have contended that there is a need to undertake a thorough assessment of the government under John Major's leadership in either preventing or suppressing genocide in Rwanda in 1994 or helping to facilitate and prolong it.81 Newsnight's failure to challenge UK politicians has further hindered a collective understanding of the extent to which the British government practiced 
denial and has prevented the sourcing of additional leads of inquiry which might expose individuals who should be held to account for failing to act on behalf of British citizens. As observed, many academic studies concentrate on the role of the UK media in influencing British foreign policy. Yet my own analysis of Newsnight suggests that one of the most crucial questions remains unanswered: to what extent were politicians influencing the Newsnight agenda? David Belton, who when interviewed appeared to be surprised that Newsnight presenters did not use the word genocide throughout the course of reporting between April and July, provides some idea of the logic behind the selection of studio guests:

I'm not sure if Newsnight tried to contact [then Minister of Foreign Affairs] Douglas Hurd and he turned them down. In my experience, the only person that matters is a government minister-preferably from the Foreign Office. It is not so important if it is a member of a party making a claim.... If he could avoid answering questions on Bosnia, think how much easier it is to avoid answering questions on Rwanda-for example "deeply regretful, monitoring the situation, doing all we can...." 82

\section{Notes}

1. See James Schofield, Silent Over Africa: Stories of War and Genocide (London: HarperCollins, 1996); Richard Dowden, "Comment: The Rwandan Genocide: How the Press Missed the Story; A Memoir," African Affairs 103, no. 411 (2004): 283-90; Tom Giles, "Media Failure over Rwanda's Genocide," BBC News, 7 April 2004, http://news.bbc. co.uk/2/hi/programmes/panorama/3599423.stm (accessed 7 January 2010); John Borton and John Eriksson, Assessment of the Impact and Influence of the Joint Evaluation of Emergency Assistance to Rwanda (Denmark: Ministry of Foreign Affair, 2004); Mark Doyle, "Reporting the Genocide," in The Media and the Rwanda Genocide, ed. Allen Thompson (London: Pluto Press, 2007), 145-59; Nick Hughes, "Exhibit 467: Genocide Through a Camera Lens," in Thompson, The Media and the Rwanda Genocide, 231-34.

2. Richard Dowden, "Comment: The Rwandan Genocide," 283.

3. Linda Melvern and Paul Williams, "Britannia Waived the Rules: The Major Government and the 1994 Rwandan Genocide," African Affairs 103, no. 410 (2004): 1-22, 3.

4. See Greg Philo et al., "The Media and the Rwanda Crisis: Effects on Audiences and Public Policy," in World Orders in the Making: Humanitarian Intervention and Beyond, ed. Jan Nederveen Pieterse (Basingstoke: Macmillan, 1998), 211-29; Alan J. Kuperman, "How the Media Missed the Rwanda Genocide," International Press Institute Report 6:1 (2000); Linda Melvern, A People Betrayed: The Role of the West in Rwanda's Genocide, rev. ed. (London: Zed Books, 2009); Anne Chaon, "Who Failed in Rwanda? The Journalists or the Media?" in Thompson, The Media and the Rwanda Genocide, 160-66; Tom Giles, "Media Failure over Rwanda's Genocide."

5. BBC, “A History of Newsnight," BBC News, 28 May 2009, http://news.bbc.co.uk/1/hi/ newsid_8070000/newsid_8072000/8072060.stm (accessed 10 January 2010).

6. George Carey, "Newsnight's Difficult Birth...," BBC News, 21 January 2005, http://news.bbc.co.uk/1/hi/programmes/newsnight/newsnight25/4111751.stm (accessed 10 January 2010).

7. Anne O'Keeffe, Investigating Media Discourse (London/New York: Routledge, 2006), 63.

8. Scott White (documentary filmmaker and director of SW Pictures), interview with the author, London, 13 February 2006.

9. Michael Leapman, "Time to Pension Off Paxman," New Statesman, 2 July 2005.

10. Will Hutton, Newsnight, BBC2, broadcast on 21 February 2002.

11. Baffour Ankomah, “Newsnight, What a Night!” New African 387 (2000): 32.

12. BBC, "A History of Newsnight."

13. Linda Melvern, Conspiracy to Murder: The Rwandan Genocide (London: Verso, 2006), 133-36. 
14. See Melvern, Conspiracy to Murder.

15. Melvern, A People Betrayed, 202.

16. Ibid., 203.

17. Ibid.

18. Ibid., 214.

19. Ibid., 289.

20. Ibid., 219.

21. Convention on the Prevention and Punishment of the Crime of Genocide, 9 December 1948, 78 U.N.T.S. 277, http://www.preventgenocide.org/law/convention/text.htm(accessed 16 May 2011).

22. Samantha Power, A Problem from Hell: America and the Age of Genocide (London: Flamingo, 2002), 49.

23. Peter Snow, Newsnight, BBC2, broadcast on 7 April 1994.

24. Kirsty Wark, Newsnight, BBC2, broadcast on 8 April 1994.

25. Ibid.

26. Tom Carver, Newsnight, BBC2, broadcast on 16 May 1994.

27. Sue Cameron, Newsnight, BBC2, broadcast on 16 May 1994.

28. Ian Lindon, Newsnight, BBC2, broadcast on 20 June 1994.

29. Theogine Rudasingwa, Newsnight, BBC2, broadcast on 20 June 1994.

30. Melvern, A People Betrayed, 325.

31. Robin Denselow, Newsnight, BBC2, broadcast on 15 July 1994.

32. Genocide scholar Martin Shaw argues that genocide should not be seen as distinct from war, but a "particular form of modern warfare, and an extension of the more common form of degenerate war." In degenerate war, civilians or certain groups of people within a society may be defined as the enemy. However, in the case of Rwanda, it seems genocide was an extreme measure implemented by the MRNDD government to retain state power. See Martin Shaw, War and Genocide (London: Polity, 2003), 5; Wark, Newsnight, BBC2, broadcast on 25 August 1994.

33. Jeremy Paxman, Newsnight, BBC2, broadcast on 22 September 1994.

34. Robin Denselow, Newsnight, BBC2, broadcast on 22 September 1994.

35. Chaon, "Who Failed in Rwanda?" 162.

36. Mark Doyle, "Reporting the Genocide," in Thompson, The Media and the Rwanda Genocide, 145.

37. Ibid., 146.

38. James Schofield (journalist), interview with the author, Oxford, 23 July 2007.

39. Geoff Adams Spink (BBC correspondent), interview with the author, London, 16 April 2007.

40. Ibid.

41. Ibid.

42. David Belton (former Newsnight producer), interview with the author, New York, 2 November 2009.

43. Ibid.

44. Ron McCullagh (head of Insight News TV), interview with the author, London, 12 December 2005.

45. Ibid.

46. Helen Fein, "Denying Genocide: From Armenia to Bosnia," LSE Occasional Paper (London: LSE, 2001).

47. Vjeko Curic, interview by Carver, Newsnight, BBC2, broadcast on 16 May 1994.

48. Carver, Newsnight, BBC2, broadcast on 16 May 1994.

49. Carver, Newsnight, BBC2, broadcast on 10 May 1994.

50. Carver, Newsnight, BBC2, broadcast on 16 May 1994.

51. Rob Wilson, interview by Carver, Newsnight, BBC2, broadcast on 10 May 1994.

52. Claude Sonier, interview by Carver, Newsnight, BBC2, broadcast on 16 May 1994.

53. Newsnight, BBC2, broadcast on 16 May 1994. 
54. Fein, "Denying Genocide," 11.

55. Cameron, Newsnight, BBC2, broadcast on 4 May 1994.

56. Peter Snow, Newsnight, BBC2, broadcast on 10 May 1994.

57. Newsnight, BBC2, broadcast on 17 May 1994.

58. Newsnight, BBC2, broadcast on 23 May 1994.

59. Newsnight, BBC2, broadcast on 20 June 1994.

60. Newsnight, BBC2, broadcast on 4 July 1994.

61. Newsnight, BBC2, broadcast on 18 July 1994; Newsnight, BBC2, broadcast on 22 July 1994.

62. Melvern, A People Betrayed, 274.

63. Ibid.

64. Oxfam campaign advert, The Times, 4 May 1994, 11.

65. Ibid.

66. Toby Jessel, Newsnight, BBC2, broadcast on 22 July 1994.

67. Wark, Newsnight Special, BBC2, broadcast on 29 July 1994.

68. Lynda Chalker, Newsnight Special, BBC2, broadcast on 29 July 1994.

69. Rakiya Omaar, Newsnight Special, BBC2, broadcast on 29 July 1994.

70. Andrew Wallis, Newsnight Special, BBC2, broadcast on 29 July 1994.

71. Desmond Tutu, Newsnight Special, BBC2, broadcast on 29 July 1994.

72. Iqbal Riza, Newsnight Special, BBC2, broadcast on 29 July 1994.

73. Brian Attwood, Newsnight Special, BBC2, broadcast on 29 July 1994.

74. Ibid.; emphasis added.

75. Nicolas Budgeon, Newsnight Special, BBC2, broadcast on 29 July 1994.

76. John Simpson, Newsnight Special, BBC2, broadcast on 29 July 1994.

77. Fein, "Denying Genocide," 2.

78. Hazel Cameron (researcher), discussion with the author, London, 31 August 2005.

79. Gavin Mount, “A 'World of Tribes,'” in Contending Images of World Politics, ed. Greg Fry and Jacintha O'Hagan (Hampshire: Macmillan Press, 2000), 151; see also Robert D. Kaplan, The Coming Anarchy: Shattering the Dreams of the Post Cold War (London: Vintage, 1992); and Samuel Huntington, Clash of Civilisation and the Remaking of World Order (New York: Simon \& Schuster, 1996).

80. Linda Melvern (investigative journalist), interview with the author, London, 4 October 2009.

81. Melvern and Williams, "Britannia Waived the Rules," 32.

82. David Belton, telephone interview with the author, New York, 2 November 2009. 